\title{
フェノール樹脂の摩擦分解によるブレーキパッド中の金属酸化物の摩擦還元*
}

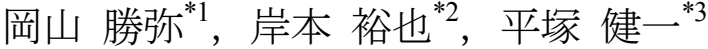

\section{Tribo-Reduction of Metal Oxides by Tribo-Degradation of Phenolic Resin in Brake Pad}

\author{
Katsuya OKAYAMA*1 ${ }^{*}$ Hiroya KISHIMOTO and Ken'ichi HIRATSUKA \\ ${ }^{* 1}$ Friction Engineering Dept., ADVICS Co., Ltd. \\ 918-11 Sakashita, Mitsukuri-cho, Toyota-shi, Aichi 470-0424, Japan
}

Brake pads are phenolic resin composites which contain several ingredients such as metal fibers, inorganic fillers, organic fillers, and so on. As previously reported, wear tests showed that pad wear varied with the type of metal oxide. Low wear was observed with the addition of metal oxides which were hardly reduced. This behavior was attributed to the frictional mechanism accompanying the tribo-degradation of phenolic resin which reduces the metal oxides at friction surface. The reduction of metal oxide associated with friction was defined as tribo-reduction. In this paper, two experiments were performed to demonstrate tribo-reduction in the friction of phenolic resin composite materials. In the first set of experiments, wear tests were conducted between cast iron or copper as disk material and pad materials to which different types of metal oxides were added. Results showed an increase in wear amount when the disk metal and the metal of the metal oxide added to the pad material were the same. This means that the reduction of metal oxide changed the friction system into similar metal contact. In the second set of experiments, samples composed of the same amount of metal oxides and phenolic resin were heated to test the chemical reactions between them. X-ray diffraction analyses showed that the metal oxides were reduced. From these results, it is clear that tribo-reduction takes place during friction of phenolic resin composite materials because of the degradation of phenolic resin.

Key Words : Wear, Tribology, Brake Pad, Composite Material, Metal Oxide, Phenolic Resin, Mild Wear, Tribo-Reduction, Tribo-Degradation

\section{1. 緒言}

自動車用ブレーキの役割は，車両を安全に停止させることであるが，最近では四輪のブレーキを各々制御し車 両の姿勢を安定させ，カーブを安全に走行できるような $\mathrm{ESC}^{(1)}$ (Electronic Stability Control）の開発も進み，その 高機能化が進んでいる。このようなブレーキの高機能化は，ブレーキパッド（以下，パッド）とディスク間の摩 擦力によって支えられているため，パッドは極めて重要な部品といえる．また，パッドには摩擦力以外にも，使 用寿命や制動時の NV (Noise Vibration), 強度など多岐にわたる性能が要求される (2)。これらの要求性能を単一 材料で満足させることは困難なため, パッドには経験的に 10〜20 種類の様々な原材料が使用され，それらがフェ ノール樹脂のバインダーによって成型された複合材となっている ${ }^{(3)}$.このような多種多様な原材料からなるパッ ドの摩耗機構は極めて複雑となり未解明なことも多いため, 現在も様々な研究が進められている(4)(5).

一方，近年では環境負荷物質の使用制限・撤廃に向けた規制が増加しており，規制対象となる原材料の代替が パッド開発の大きな課題となっている ${ }^{(6)}$.また，ハイブリッド自動車や電気自動車の普及に伴い，ブレーキ部品

* 原稿受付 2013 年 1 月 23 日

*1 正員, (株)アドヴィックス フリクション技術部（テ470-0424 愛知県豊田市御作町坂下 918-11）

*2 (株) アドヴィックスフリクション技術部

*3 正員, 千葉工業大学 工学部 機械サイエンス学科（†275-0016 千葉県習志野市津田沼 2-17-1）

E-mail: katsuya_okayama@nts.advics.co.jp 
の小型・軽量化がより一層求められ，パッドに対しても摺動面積や厚みの減少などが要求されることになる.こ のように, パッドを取り巻く環境は大きく変化してきており, パッド開発の現場にはこれらの変化に迅速に対応 することが求められている.

以上の背景から，著者らはパッドの摩耗機構の解明に主眼を置きながら，パッドの耐摩耗性向上の新たな方策 を探る取り組みを進めている。これまでに，パッド材の組成を簡素化したフェノール樹脂複合材を用い，サブミ クロンから $1 \mu \mathrm{m}$ 程度の微細な金属酸化物の摩耗特性に対する添加効果, ならびにその摩耗機構の解析を行って きた．その結果，添加した金属酸化物の種類によってパッド材摩耗量が異なることを明らかにした．また，添加 した金属酸化物の還元されやすさの指標に，酸化物の標準生成自由エネルギーを用いることで，パッド材摩耗量 を整理できることを示した．これは，摩擦面で金属酸化物の還元を伴った摩耗機構が存在すると推定したためで ある.さらに，還元反応にはフェノール樹脂の分解が関与していることを示した (7). 著者らは，このような摩擦 面で生じる金属酸化物の還元反応を摩擦還元と位置づけ, パッド材の摩耗時における重要な現象の一つとしてと らえた.

ところが， $\mathrm{Fe}_{3} \mathrm{O}_{4}$ を添加したパッド材は，前述の金属酸化物の還元のされやすさとパッド材摩耗量の傾向から 大きく外れた. $\mathrm{Fe}_{3} \mathrm{O}_{4}$ は還元されると金属の $\mathrm{Fe}$ (鉄) を生成するが，この $\mathrm{Fe}$ はディスク材と同種金属になる．し たがって，パッド材摩擦面に生成された Fe とディスク材の $\mathrm{Fe}$ との “ともが祆”による凝着性の高い摩擦状態と なるために, 摩耗量が極端に増大寸る特異性を示すと推察した. しかしながら, 既報ではこの推定機構を十分に 検証するに至らなかった.

そこで, 本論文では $\mathrm{Fe}_{3} \mathrm{O}_{4}$ を添加したパッド材摩耗量に特異性が生じた原因を解明し, パッド材の摩耗機構に は金属酸化物の摩擦還元が伴うことを明らかにするため, 以下の二つの取り組みを行った.

(1) $\mathrm{Fe}_{3} \mathrm{O}_{4}$ を添加したパッド材では, 摩擦還元によって $\mathrm{Fe}$ が生成され，ディスク材の $\mathrm{Fe}$ との “ともがね” 状態 になることで特異性を示すのであれば，逆にこの特異性を利用することで摩擦還元の存在を明確にできる．すな わち, ディスク材金属の種類とパッド材に添加する金属酸化物の種類を変更して, 還元されると “ともが叔” なるような組み合わせを, Fe 以外の金属を使って意図的に作り出し, 摩耗試験によって摩擦還元の存在を検証す るものである. 具体的には，ディスク材に $\mathrm{Cu}$ を用い，パッド材には $\mathrm{CuO}$ を添加して摩耗試験を行った．摩擦還 元が生じるならば, この組み合わせにおいてもディスク材に $\mathrm{Fe}$ を用いた場合と同様に摩耗量が増大寸るはずである. この内容を 2 章の「摩耗試験」に記載した.

(2) 摩擦還元発現の推定原因に挙げたフェノール樹脂分解について, 既報ではフェノール樹脂・金属酸化物 $(\alpha$ $-\mathrm{Fe}_{2} \mathrm{O}_{3}$ ) の混合試料を加熱し，金属酸化物の還元の有無を調べる実験を行った．本論文では金属酸化物の種類を 増やして上記の加熱実験を行うとともに，新たに金属酸化物の組成変化をX 線回折にて詳しく調へ，摩擦還元の 原因にはフェノール樹脂の分解が関与していることを明らかにした。この内容を 3 章の「金属酸化物の還元に対 するフェノール樹脂分解の影響」で述べた．さらに，フェノール樹脂分解時にどのような機構で金属酸化物が還 元されるのかについても検討した。 これを 4 章の「金属酸化物還元の機構」に記載した.

以上の取り組みから，フェノール樹脂複合材の摩耗時には金属酸化物の摩擦還元が伴うという推定機構に新た な検証結果を加えることができ，パッド材の摩耗時の現象解明に対して有用な知見が得られたので報告する.

\section{2. 摩耗試験}

\section{$2 \cdot 1$ 試料の作製}

本論文では，既報(7)で用いたパッド材と同様に，フェノール樹脂，アラミド繊維，硫酸バリウム，水酸化カル シウムの 4 種類に金属酸化物を 1 種類加えた合計 5 種類の原材料からなるパッド材を試作した。 パッド材の配合 を表 1 に示す．金属酸化物には，摩擦還元によるディスク材との “ともが㸚” 状態を作り出すことを狙い，ディ スク材と同じ金属からなる 2 種類の酸化物（ $\mathrm{Fe}_{3} \mathrm{O}_{4}$ と $\mathrm{CuO} ）$ を用いた．その詳細を表 2 に示す.

パッド材の作製方法は以下の通りである.まず，上記 5 種類の原材料をミキサーにて 3 分間混合し，その粉を 金型に投入した後, $160^{\circ} \mathrm{C} て 5$ 分間の熱成型を行った. 得られた成型品を $210^{\circ} \mathrm{C} ・ 3$ 時間で熱処理を行い，その 後, 外径 $30 \mathrm{~mm}$, 厚み $5 \mathrm{~mm}$ に機械加工しパッド材を製作した。一方，相手材となるディスク材には表 3 に示した 鋳鉄（FC200）とタフピッチ銅（C1100）の2 種類を用いた。鋳鉄のディスク材については, 実際の車両に装着さ 
れているディスクから機械加工によって外径 $30 \mathrm{~mm}$ ，厚み $2 \mathrm{~mm}$ の試験片を切り出して製作した. タフピッチ銅に ついては，市販材料を所定寸法に機械加工して製作した，それぞれの試料の外観を図 1 に示寸.

Table 1 Formulation of pad specimens

\begin{tabular}{c|c|c}
\hline Ingredient & Composition & Content [Vol. \%] \\
\hline \hline Phenolic resin & $-\left(\mathrm{C}_{6} \mathrm{H}_{4}-\mathrm{OH}-\mathrm{CH}_{2}\right)_{\mathrm{n}}-$ & 20 \\
\hline Aramid fiber & $-\left(\mathrm{NH}-\mathrm{C}_{6} \mathrm{H}_{4}-\mathrm{NH}-\mathrm{CO}-\mathrm{C}_{6} \mathrm{H}_{4}-\mathrm{CO}\right)_{\mathrm{n}}-$ & 10 \\
\hline Barium sulfate & $\mathrm{BaSO}_{4}$ & 63 \\
\hline Calcium hydroxide & $\mathrm{Ca}(\mathrm{OH})_{2}$ & 2 \\
\hline Metal oxide & $\mathrm{Fe}_{3} \mathrm{O}_{4}, \mathrm{CuO}$ & 5 \\
\hline \hline
\end{tabular}

Table 2 Specification of metal oxides as a pad additive

\begin{tabular}{c|c|c}
\hline Pad specimen & Pad I & Pad II \\
\hline \hline Metal oxide & $\mathrm{Fe}_{3} \mathrm{O}_{4}$ & $\mathrm{CuO}$ \\
\hline Median diameter $[\mu \mathrm{m}]$ & 0.30 & 0.92 \\
\hline Mohs hardness & $5.5 \sim 6.5^{(8)}$ & $3.5^{(9)}$ \\
\hline
\end{tabular}
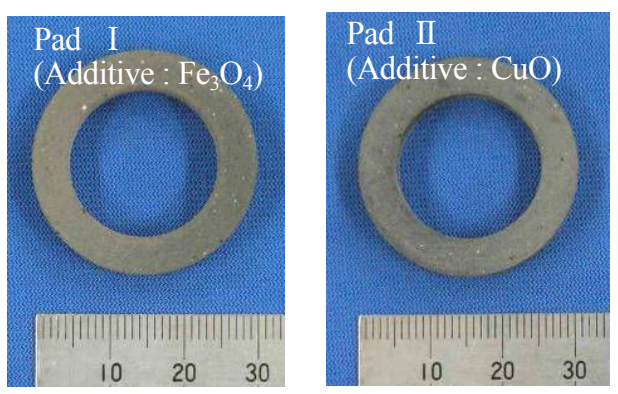

(a) Pad specimen
Table 3 Specification of disk specimens

\begin{tabular}{c|c|c}
\hline Material & $\begin{array}{c}\text { Cast iron } \\
(\mathrm{FC} 200)\end{array}$ & $\begin{array}{c}\text { Tough pitch copper } \\
(\mathrm{C} 1100)\end{array}$ \\
\hline Mohs hardness & $4.5^{(10)}$ & $2.5 \sim 3.0^{(9)}$ \\
\hline
\end{tabular}
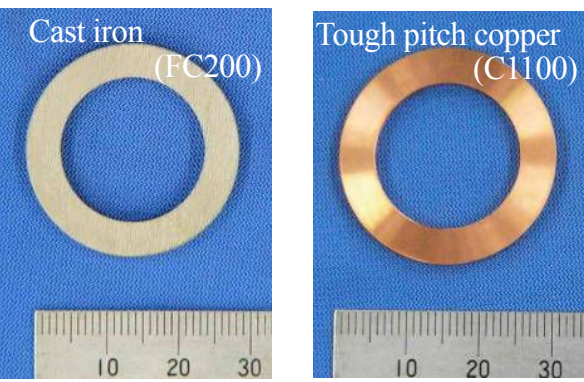

(b) Disk specimen

Fig. 1 Test specimen images

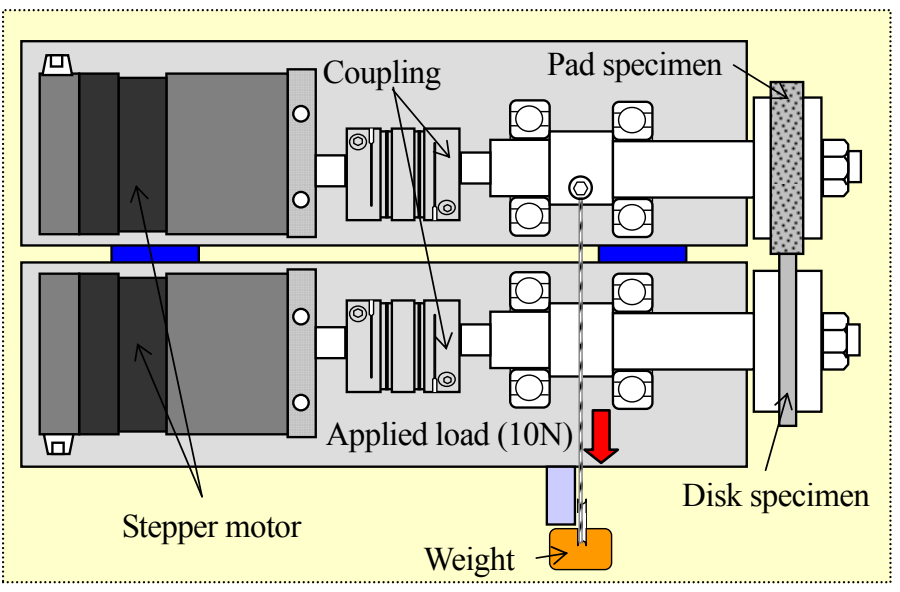

(a) Schematic of twin-ring tribometer

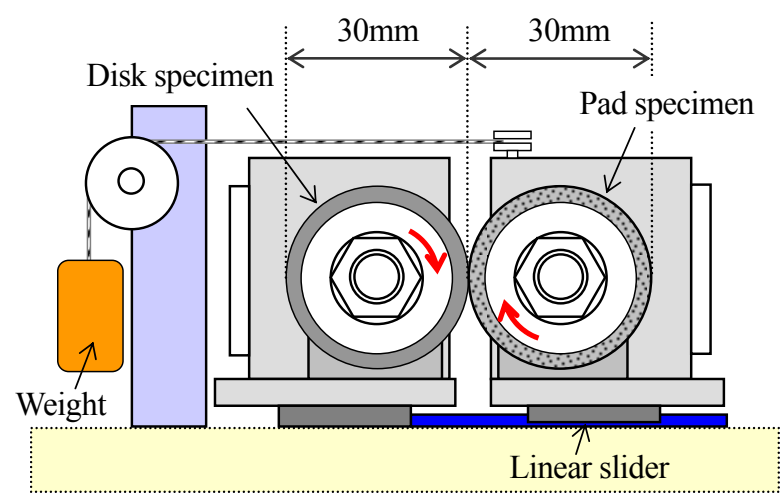

(b) Setup of test specimens

Fig. 2 Apparatus for wear test 


\section{$2 \cdot 2$ 摩耗試験方法}

摩耗試験に用いたツィンリング試験機 ${ }^{11)}$ の全体を図 2 (a) に示す. $2 \cdot 1$ で製作した試料を図 2 (b) のように取り 付け，ディスク材にパッド材を $10 \mathrm{~N}$ で押し付けて両試料を同回転方向・同回転速度で回転させ，接触界面に相対 摺動速度 $400 \mathrm{~mm} / \mathrm{s}$ の寸べり摩擦を生じさせた．これは，実際の車両が国内市街地で走行した際によく観測される 制動条件から設定した值である．ただし，ツィンリング試験機では，試験片の外径および回転数の制限から，実 際の制動条件に比べ摺動速度が約 1/5 1/10 程度になっている.このため, 押し付け荷重を高く設定し, 試験負 荷としての PV 值（P : 荷重，V：摺動速度）を実際の制動条件に合わせた。また，試験片温度は国内市街地でよ く使用されるブレーキ温度の $100^{\circ} \mathrm{C}$ に設定した。実験条件の詳細を表 4 に示す。なお，パッド材の摩耗量は試験 前後の試料片の質量変化から算出した。 また, 摩耗機構解明のために試験後の摩擦面および摩耗粉を電界放射型 走査電子顕微鏡（FE-SEM）を用いて観察した。

\section{$2 \cdot 3$ 摩耗試験結果}

摩耗試験の結果を図 3 に示寸、鋳鉄をディスク材に用いた場合, $\mathrm{CuO}$ の添加に比べ $\mathrm{Fe}_{3} \mathrm{O}_{4}$ を添加したパッド材 の摩耗量が多いことがわかる. 反対に，タフピッチ銅（C1100）をディスク材に用いた場合には， $\mathrm{Fe}_{3} \mathrm{O}_{4}$ の添加に 比べ $\mathrm{CuO}$ を添加したパッド材の摩耗量が多くなっていることが確認できる.つまり, 鋳鉄およびタフピッチ銅の いずれを用いても，ディスク材と同種金属からなる酸化物をパッド材に添加した場合には，ディスク材と異種の 金属からなる酸化物の添加に比べ，その摩耗量が増大寸ることがわかる．詳細を $2 \cdot 5$ で述べるが，これは金属酸 化物の摩擦還元が生じたことを示寸結果と結論付けられる．ただし，ディスク材の材質を変更したことにより， パッド材の摩耗機構が大きく変化する可能性もあるため, パッド材, ディスク材および摩耗粉を観察し，ディス ク材金属の種類を変えたことによる摩耗機構への影響を調べた.

Table 4 Wear test condition

\begin{tabular}{l|c|c}
\hline \multirow{2}{*}{$\begin{array}{l}\text { Pad } \\
\text { specimen }\end{array}$} & Additive & $\begin{array}{c}\mathrm{Pad} \mathrm{I}: \mathrm{Fe}_{3} \mathrm{O}_{4} \\
\mathrm{Pad} \mathrm{II}: \mathrm{CuO}\end{array}$ \\
\cline { 2 - 3 } & Size $[\mathrm{mm}]$ & $\phi 30 \times 5^{\mathrm{t}}$ \\
\hline \multirow{2}{*}{$\begin{array}{l}\text { Disk } \\
\text { specimen }\end{array}$} & Material & $\begin{array}{c}\text { Cast iron }(\mathrm{FC} 200) \\
\text { Tough pitch copper }(\mathrm{C} 1100)\end{array}$ \\
\cline { 2 - 3 } & Size $[\mathrm{mm}]$ & $\phi 30 \times 2^{\mathrm{t}}$ \\
\hline \multicolumn{2}{c}{ Disk temperature $\left[{ }^{\circ} \mathrm{C}\right]$} & 100 \\
\hline \multicolumn{2}{c}{ Applied load $[\mathrm{N}]$} & 10 \\
\hline \multicolumn{2}{c}{ Sliding velocity $[\mathrm{mm} / \mathrm{s}]$} & 400 \\
\hline \multicolumn{2}{c}{ Sliding distance $[\mathrm{km}]$} & 100 \\
\hline
\end{tabular}

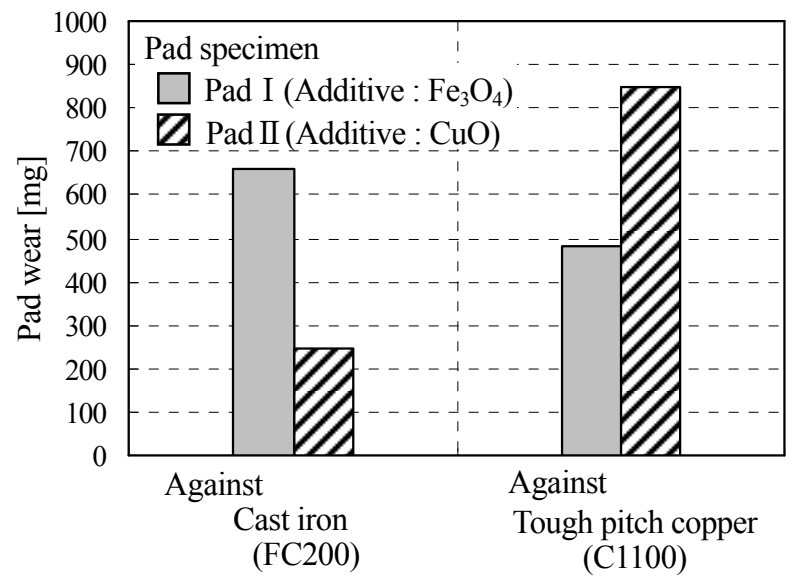

Fig.3 Effects of metal oxide additives on the wear of pads rubbed against cast iron and tough pitch copper

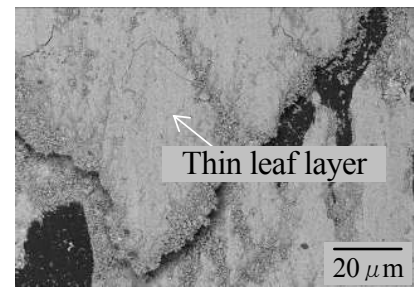

(a) $\mathrm{Pad}$ I (Additive : $\mathrm{Fe}_{3} \mathrm{O}_{4}$ )

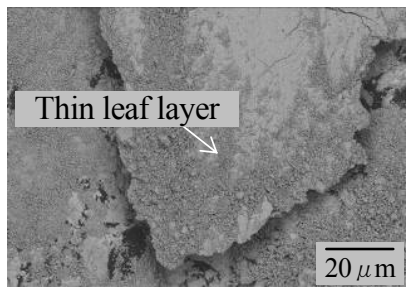

(b) Pad II (Additive : $\mathrm{CuO}$ )

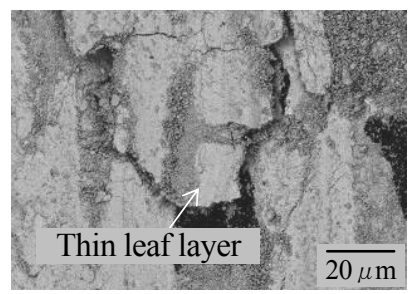

(c) Pad I (Additive : $\mathrm{Fe}_{3} \mathrm{O}_{4}$ )

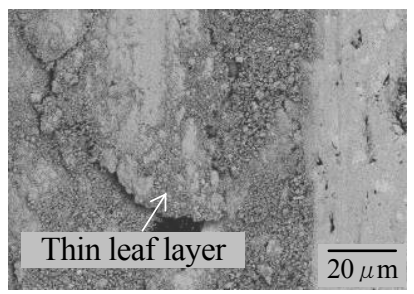

(d) $\mathrm{Pad}$ II (Additive : $\mathrm{CuO}$ )

Against Cast iron (FC200)

Fig.4 SEM micrographs of pad worn surfaces 


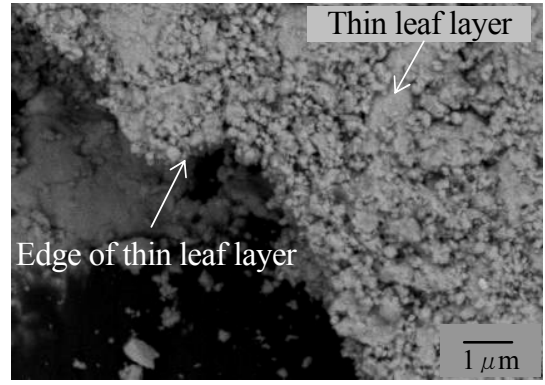

(a) Against Cast iron (FC200)

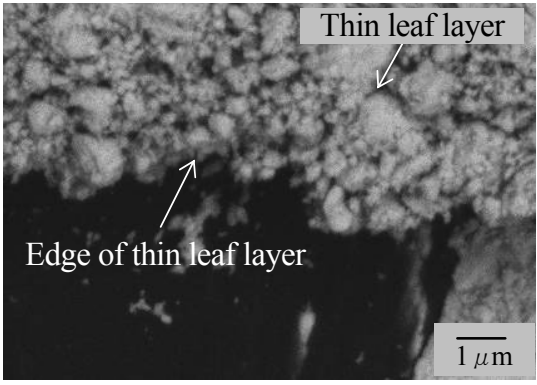

(b) Against Tough pitch copper (C1100)

Fig. 5 Enlarged views of thin leaf layer on Pad I (Additive : $\mathrm{Fe}_{3} \mathrm{O}_{4}$ ) worn surfaces

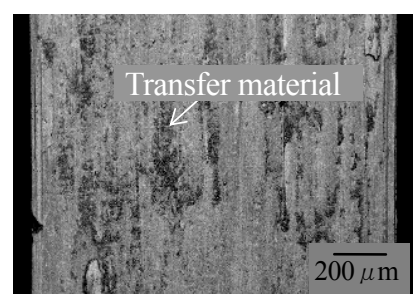

(a) Against Pad I (Additive : $\mathrm{Fe}_{3} \mathrm{O}_{4}$ )

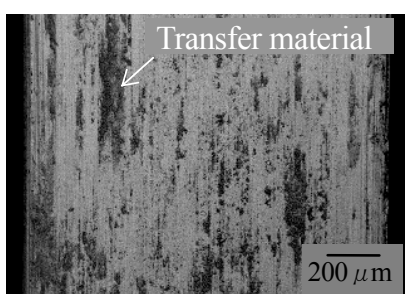

(b) Against Pad II (Additive : $\mathrm{CuO}$ )

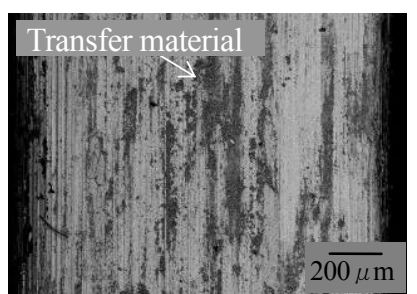

(c) Against Pad I (Additive : $\mathrm{Fe}_{3} \mathrm{O}_{4}$ )

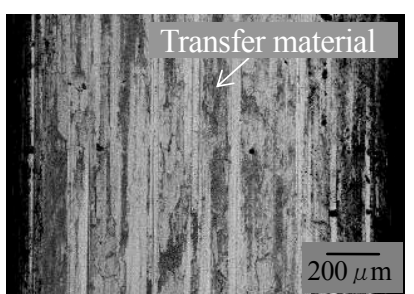

(d) Against Pad II (Additive : $\mathrm{CuO}$ )

Disk specimen : Cast iron (FC200)

Disk specimen : Tough pitch copper (C1100)

Fig. 6 SEM micrographs of worn surfaces of disk specimens

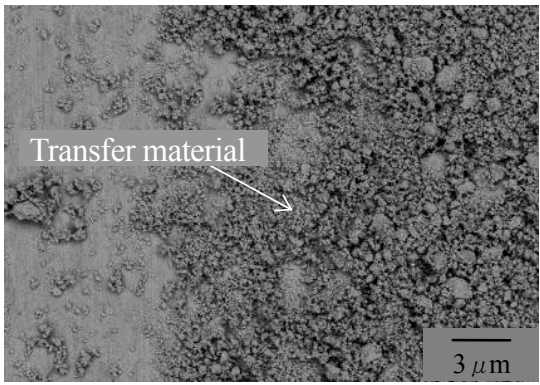

(a) Disk specimen : Cast iron (FC200)

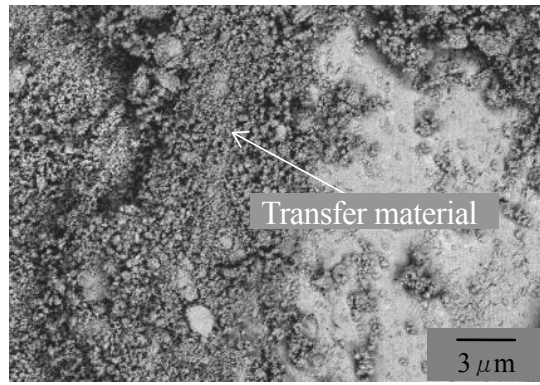

(b) Disk specimen : Tough pitch copper (C1100)

Fig. 7 Enlarged views of transfer material on disk surfaces rubbed against Pad I (Additive : $\mathrm{Fe}_{3} \mathrm{O}_{4}$ )

\section{$2 \cdot 4$ 摩擦面および摩耗粉の観察結果}

パッド材の摩擦面観察結果を図 4 に示す.鋳鉄およびタフピッチ銅のいずれをディスク材に用いた場合でも, パッド材摩擦面には鱗片状組織が観察された。この鱗片状組織の拡大画像を図 5 に示寸. 鱗片状組織には $1 \mu \mathrm{m}$ 以下の微細な摩耗粉が観察されることから, 摩擦面で生成された微細な摩耗粉が凝集・固結して形成された被膜 層(7)であると確認される.

ディスク材摩擦面の観察結果を図 6 に示寸.ディスク材の摩擦面には黒色部が多く観察された. この黒色部を 拡大寸ると, 図 7 のように $1 \mu \mathrm{m}$ 以下の摩耗粉が凝集した状態となっている. これは, 摩擦面で生成された微細 な摩耗粉が凝集し，それがディスク材に移着したものと推定できる．この移着物は，鋳鉄およびタフピッチ銅の いずれをディスク材に用いた場合にも観察された.

試験時に回収した摩耗粉の観察結果を図 8 に示寸. いずれの試料からも，50〜200 $\mu \mathrm{m}$ 程度の粗大摩耗粉が 多く観察された. 粗大摩耗粉の多くは, 図 9(a), (b)に示したように鱗片状を呈しており, 拡大すると $1 \mu \mathrm{m}$ 以下 の微細な粒子が凝集した状態であることがわかる（図 $9\left(\mathrm{a}^{\prime}\right)$, ( $\left.\left.\mathrm{b}^{\prime}\right)\right)$. 既報 ${ }^{(7)}$ の結果を踏まえると, 粗大摩耗粉はパ ッド材の摩擦面に形成された被膜層が脱落して生成されたものと推定できる.

以上の結果から，ディスク材金属の材質を変えたことによるパッド材摩擦面，ディスク材摩擦面および摩耗粉 の状態には，大きな違いが認められないことがわかる. 


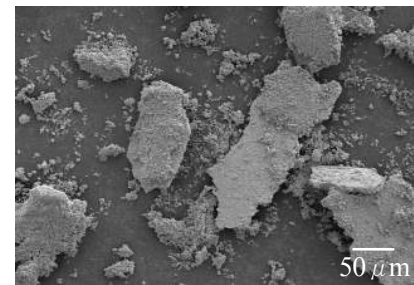

(a) Pad I (Additive : $\mathrm{Fe}_{3} \mathrm{O}_{4}$ )

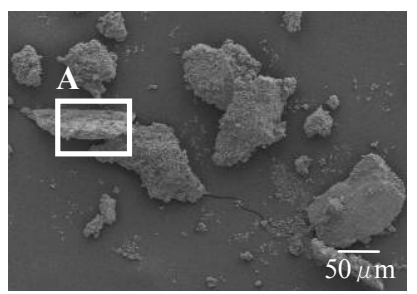

(b) Pad II (Additive : $\mathrm{CuO}$ )

Against Cast iron (FC200)

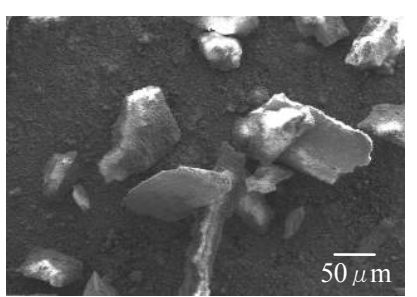

(c) Pad I (Additive : $\mathrm{Fe}_{3} \mathrm{O}_{4}$ )

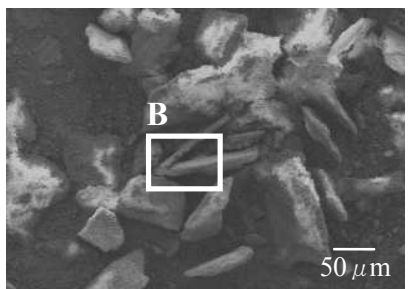

(d) Pad II (Additive : $\mathrm{CuO}$ )

Against Tough pitch copper $(\mathrm{C} 1100)$

Fig. 8 SEM micrographs of wear debris

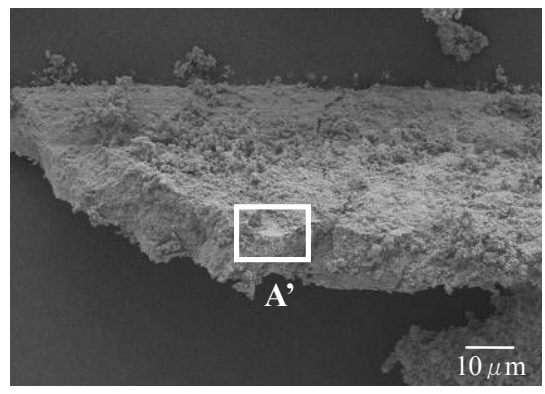

(a) Enlarged view of area A in Fig.8

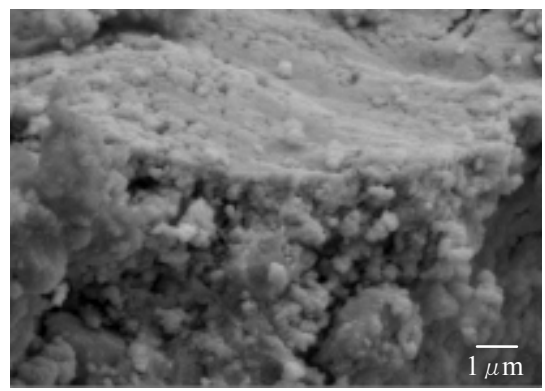

(a') Enlarged view of area A'

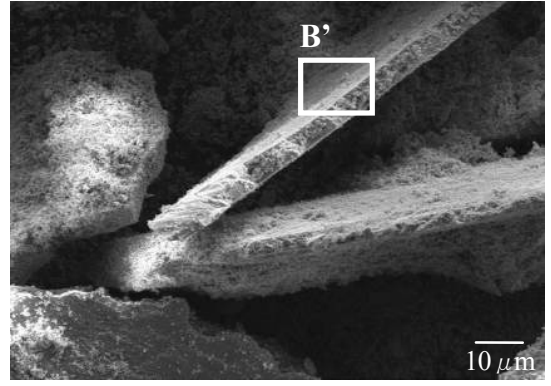

(b) Enlarged view of area B in Fig.8

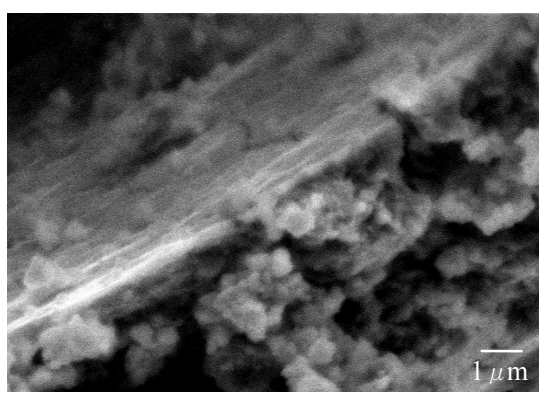

(b') Enlarged view of area B'

Fig. 9 Enlarged views of wear debris

\section{$2 \cdot 5$ ディスク材金属の材質違いによる摩耗機構の考察と摩擦還元の検証}

パッド材，ディスク材の摩擦面および摩耗粉の観察結果から，ディスク材金属の材質を変化させても，パッド材 の摩耗機構は既報(7) と同じと結論付けられる. その摩耗機構を図 10 に示す.

パッド材とディスク材の摩擦面では，真実接触部で剪断破壊が生じ微細な摩耗粉が生成される．生成された微細 な摩耗粉は, 摩擦面で圧縮・剪断力を繰り返し受けることによって摩耗粉同士が凝集・固結し，パッド材摩擦面に 被膜層を形成する (図 10 (1)）．被膜層は，ディスク材への凝着によってパッド材摩擦面から一部が脱落すると，粗 大摩耗粉として排出され（図 10 (2)，(3)），パッド材の摩耗が進行する. ディスク材との凝着性が高い場合には，被 膜層の脱落が促進されてパッド材の摩耗量が増大寸ることになる.

ここで，被膜層とディスク材との凝着性が高くなる要因を考察する。一般に，凝着性は金属と金属酸化物などの 非金属との接触では低く，金属と金属との接触では高いことが知られている ${ }^{(12)}$.また，金属と金属との摩擦では同 種金属同士の “ともがね”となる場合に凝着性は極めて高くなる．これらを踏まえ，摩擦還元によるディスク材金 属とパッド材に添加した金属酸化物との凝着性の変化を図 11 にまとめた.

ディスク材金属とパッド材に添加した金属酸化物が摩擦する凝着性の低い状態（図 11 の左部分）では, ディスク 材金属の種類およびパッド材に添加した金属酸化物の種類が変化しても, それらの間の凝着性に大きな違いは生じ ない.つまり，ディスク材に鋳鉄およびタフピッチ銅のいずれを用いても，パッド材に添加した金属酸化物の種類 によるディスク材との凝着性はあまり変わらない，ところが，摩耗試験の結果はディスク材と同種の金属からなる 
酸化物を添加した場合に摩耗量が増大寸る結果を示した。これは, 図 11 の右部分に示したように金属酸化物が摩擦 還元されることを仮定すれば説明できる.すなわち，摩擦時には添加した金属酸化物が還元されて，ディスク材金 属との間で金属同士の摩擦が生じる．この際，還元によって生成された金属とディスク材との間で同種金属となれ ば，“ともがね”による凝着性の高い状態が発現し，パッド材摩耗量が極端に増大寸るというものである.

以上の考察から，摩耗試験の結果は摩擦還元を伴う摩耗機構を実証した結果と結論付けられる.

\section{(1)}

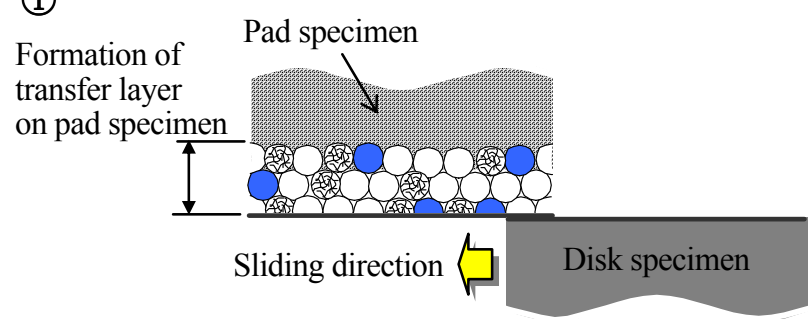

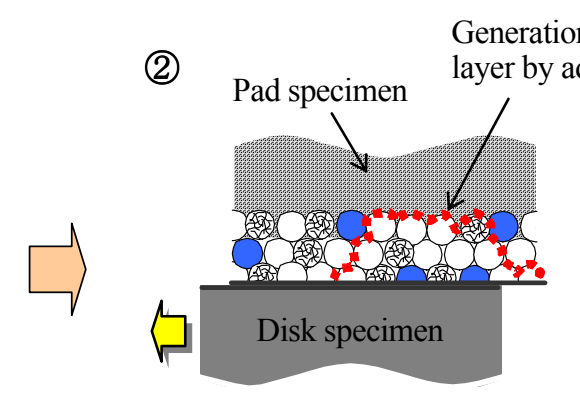

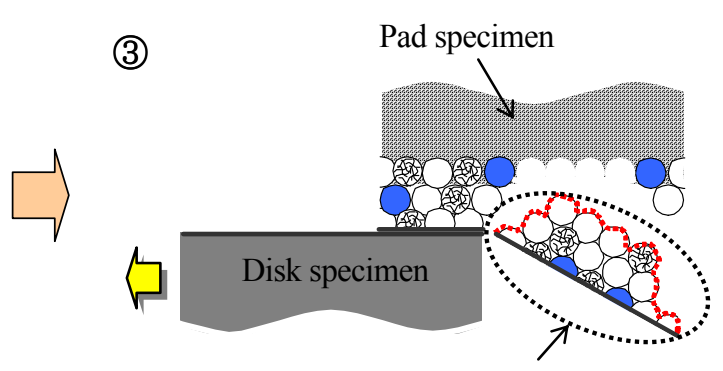

Coarse wear debris

Fig.10 Pad wear process

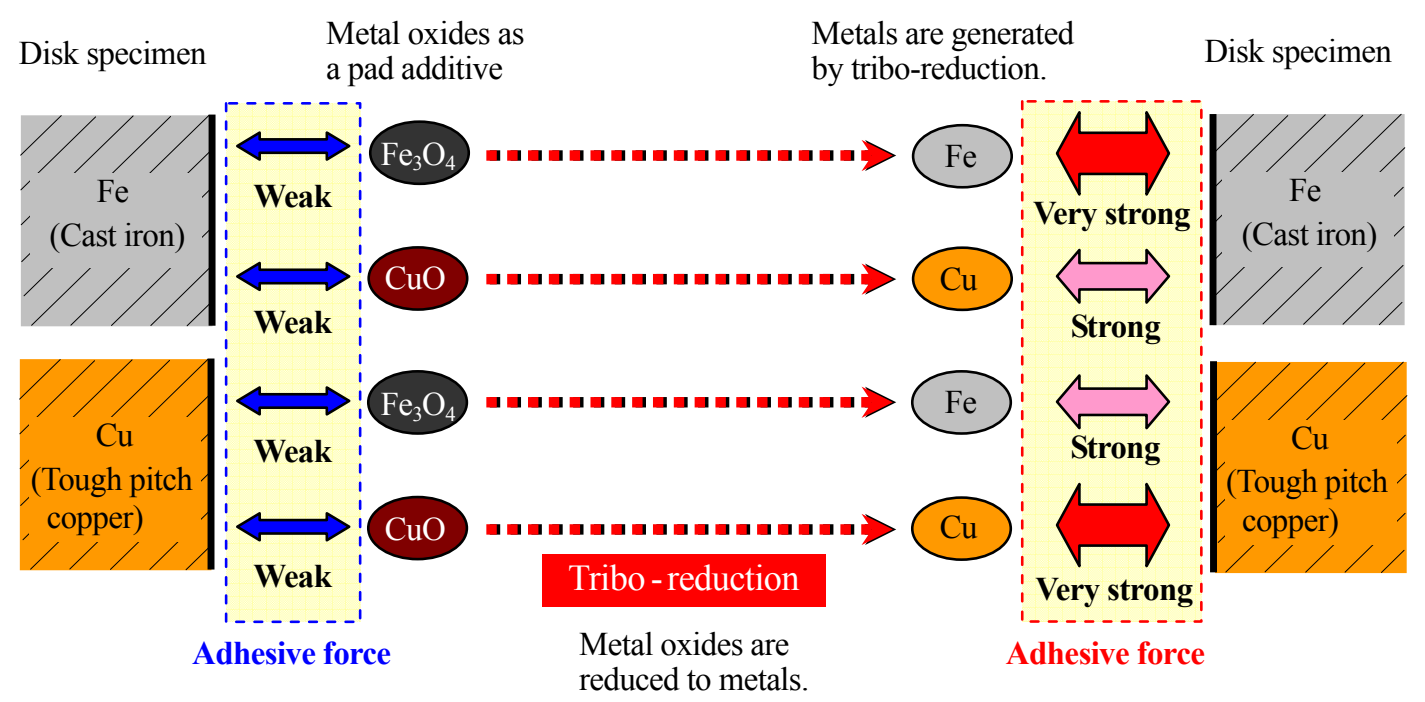

Fig. 11 Effects of tribo-reduction of metal oxides on their adhesive forces on to metal disk specimens 


\section{3. 金属酸化物の還元に対するフェノール樹脂分解の影響}

既報(7)において，摩擦時に生じる金属酸化物の還元には，フェノール樹脂の分解が関与寸ると推定した．本論 文では，上記の推定を検証するため，フェノール樹脂・金属酸化物の混合試料を加熱し，フェノール樹脂を熱分 解させた場合の金属酸化物の還元の有無について詳しく調べた．実験方法を次に示す．

フェノール樹脂と金属酸化物の重量比が $1: 1$ となるように計量し，メノウ乳鉢上で両者が均一になるまで混合した. なお,フェノール樹脂については $210^{\circ} \mathrm{C} て ゙ 3$ 時間で硬化処理を行った後に, あらかじめ乳鉢で細かく粉砕したものを用い た. 金属酸化物には，摩耗試験に用いた $\mathrm{Fe}_{3} \mathrm{O}_{4}$ と $\mathrm{CuO}$ を選定した。実験装置には，図 12 に示寸熱重量測定装置（株島津 製作所製 DTA50）を用い，金属酸化物が還元されて金属が生じた場合，その金属が酸化されて再び金属酸化物となるこ とを抑制するため，窒素ガスを $80 \mathrm{ml} / \mathrm{min}$.でパージした．これらの各試料を白金 $(\mathrm{Pt})$ 製セルに入れ，室温から $800^{\circ} \mathrm{C}$ ま゙ 昇温速度 $10^{\circ} \mathrm{C} / \mathrm{min}$. にて加熱し，フェノール樹脂を熱分解させた．フェノール樹脂の影響を明確にするため，フェノー ル樹脂を含まない金属酸化物のみの $\mathrm{Fe}_{3} \mathrm{O}_{4}$ および $\mathrm{CuO}$ についても同様の実験を行い，結果を比較した．実験条件を表 5 に，セルに試料をセットした状態を図 13 に示す．試料の変化をとらえるため，光学顕微鏡を用いて実験前後の試料を観 察するとともに，X線回折により組成を同定した.

図 14 に加熱時の各試料の質量変化を示す.フェノール樹脂のみの試料では, $400 \sim 600^{\circ} \mathrm{Cで}$ 質量が大きく減少し, この温度範囲でフェノール樹脂の分解が認められる. 試験前後の質量を比較すると, 減少量は $2.35 \mathrm{mg}$ であるこ とが確認できる．また，金属酸化物のみの $\mathrm{Fe}_{3} \mathrm{O}_{4}$ および $\mathrm{CuO}$ については質量変化がほとんどみられず，両者の結 果はほぼ重なっている。一方，フェノール樹脂・ $\mathrm{Fe}_{3} \mathrm{O}_{4}$ の混合試料およびフェノール樹脂・ $\mathrm{CuO}$ の混合試料にお ける試験前後の質量差は，それぞれ $2.87 \mathrm{mg}$ と $3.53 \mathrm{mg}$ であり，いずれもフェノール樹脂のみを加熱した場合より も質量が多く減少した．これは，フェノール樹脂の分解に加え，金属酸化物から酸素が奪われたことによる金属 酸化物の質量減が含まれていることを示している．なお，フェノール樹脂と $\mathrm{Fe}_{3} \mathrm{O}_{4}$ を混合した試料に比べ $\mathrm{CuO}$ と 混合した試料では，フェノール樹脂の分解が始まる $400^{\circ} \mathrm{C}$ から質量が大きく減少し，また試験終了時の質量減少 も多い. これは, $\mathrm{Fe}_{3} \mathrm{O}_{4}$ よりも $\mathrm{CuO}$ が還元されや寸いため, フェノール樹脂の分解初期で $\mathrm{CuO}$ の還元が急激に進 むこと，ならびにより多くの酸素が奪われたことによると解釈される.
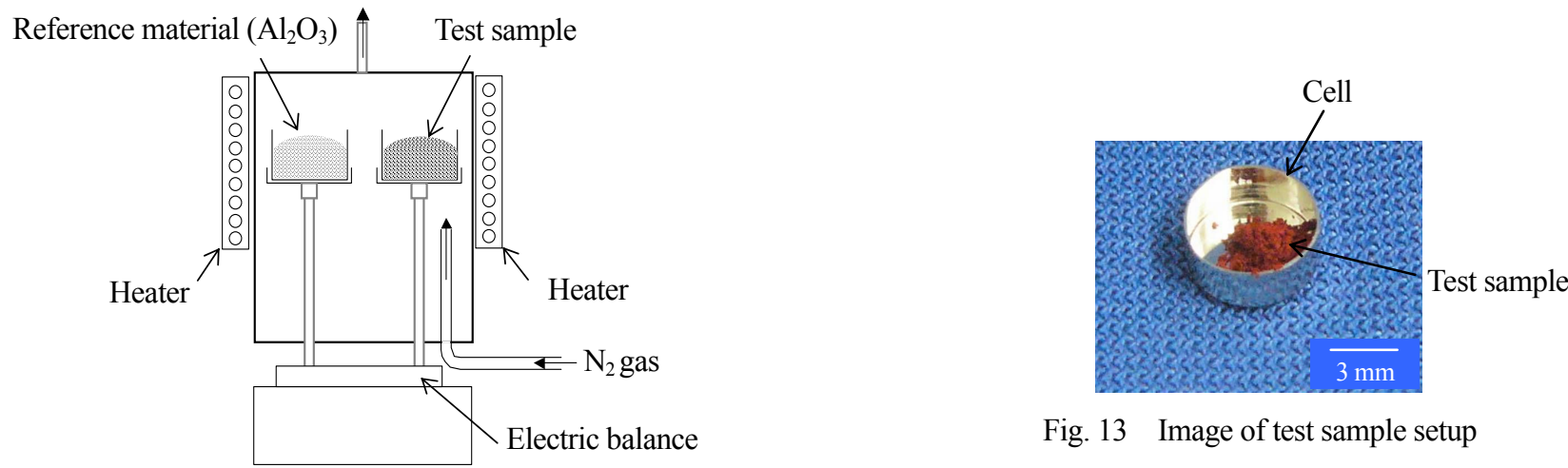

Fig. 13 Image of test sample setup

Fig. 12 Schematic diagram of heating test

Table 5 Test conditions of the heating test

\begin{tabular}{c|l}
\hline \multirow{3}{*}{ Sample } & (1) $\mathrm{Phenolic} \mathrm{resin}(5 \mathrm{mg})^{\text {(2) } \mathrm{Fe}_{3} \mathrm{O}_{4}(5 \mathrm{mg})}$ \\
& (3) $\mathrm{CuO}(5 \mathrm{mg})$ \\
& $\begin{array}{l}\text { (4) Phenolic resin }(5 \mathrm{mg})+\mathrm{Fe}_{3} \mathrm{O}_{4}(5 \mathrm{mg}) \\
\text { (5) Phenolic resin }(5 \mathrm{mg})+\mathrm{CuO}(5 \mathrm{mg})\end{array}$ \\
\hline Temperature & R.T. $\sim 800{ }^{\circ} \mathrm{C}$ \\
\hline Gas purge & $\mathrm{N}_{2}(80 \mathrm{ml} / \mathrm{min})$. \\
\hline Cell material & $\mathrm{Pt}$ \\
\hline
\end{tabular}

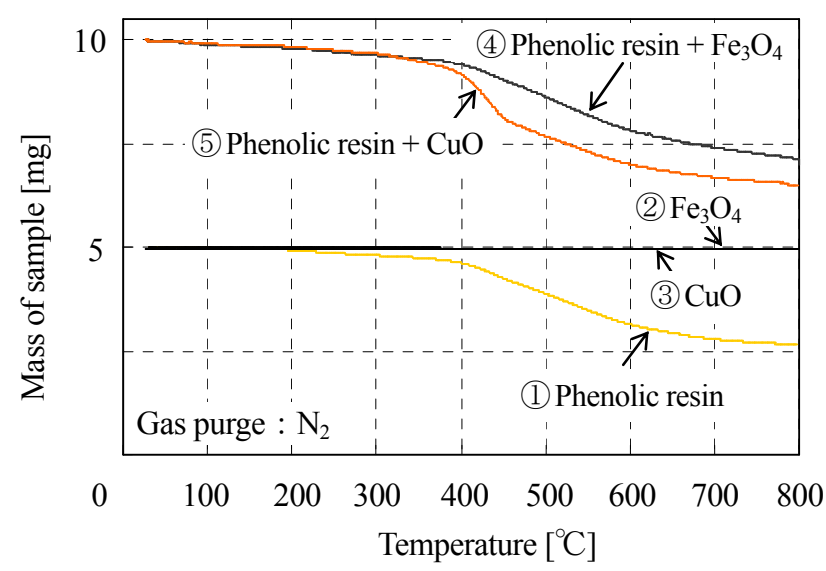

Fig. 14 Thermal gravimetric analysis with or without phenolic resin 
表 6 に加熱前後の各試料の光学顕微鏡による観察結果を示す．フェノール樹脂のみでは，加熱によって試料は 黄から黒に変色しており，フェノール樹脂が分解して炭化したことがわかる．また，金属酸化物のみの試験にお いて, $\mathrm{Fe}_{3} \mathrm{O}_{4}$ は黒色から赤色に一部変化したが， $\mathrm{CuO}$ には色の変化が認められなかった。一方，フェノール樹脂・ 金属酸化物の混合試料では， $\mathrm{CuO}$ と混合した試料で黒色から橙色へと変化した．なお， $\mathrm{Fe}_{3} \mathrm{O}_{4}$ と混合した試料に ついては色の変化がみられなかった。

Table 6 Optical micrographs of test samples before and after the heating test

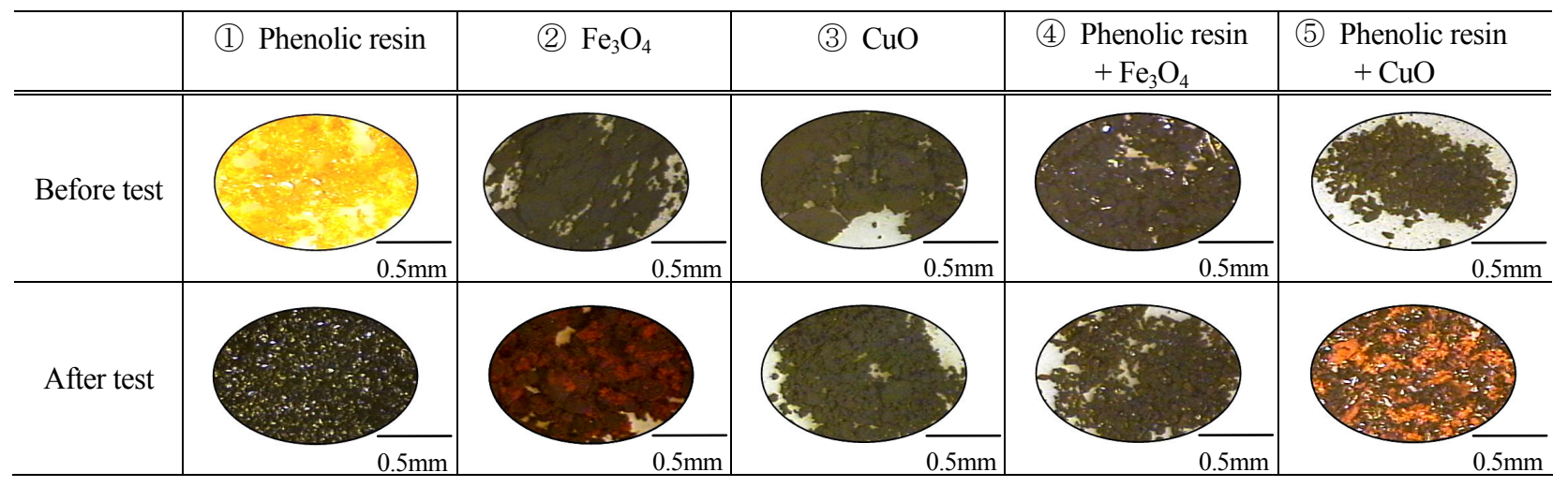

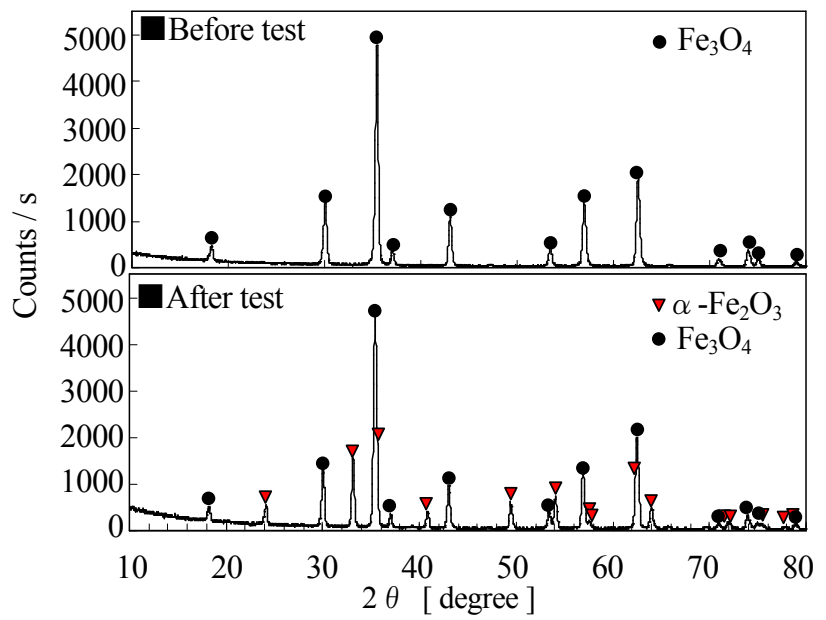

(a) $\mathrm{Fe}_{3} \mathrm{O}_{4}$

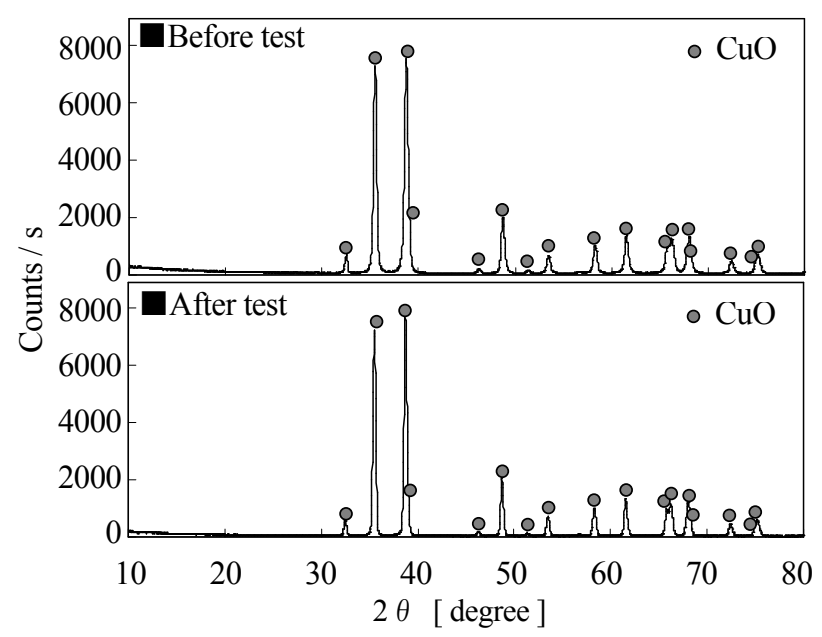

(c) $\mathrm{CuO}$

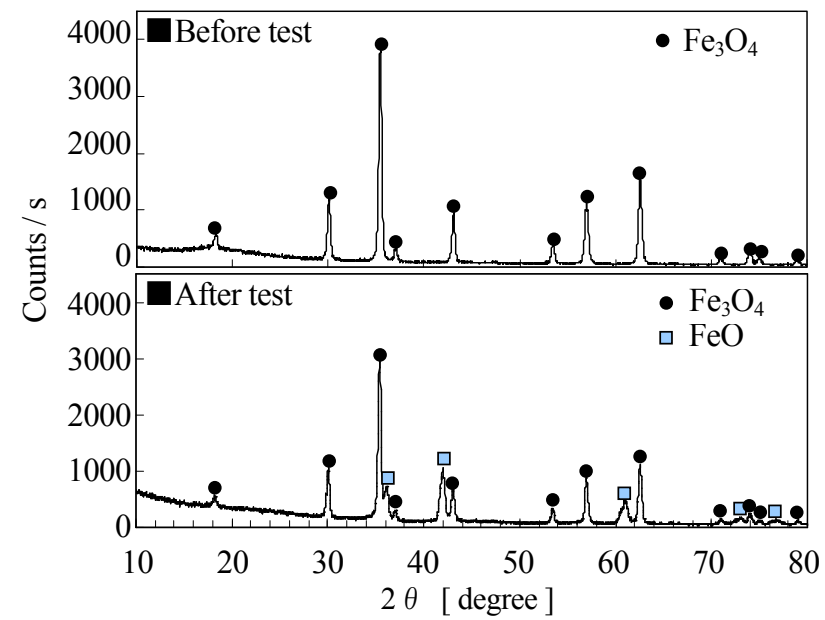

(b) Phenolic resin $+\mathrm{Fe}_{3} \mathrm{O}_{4}$

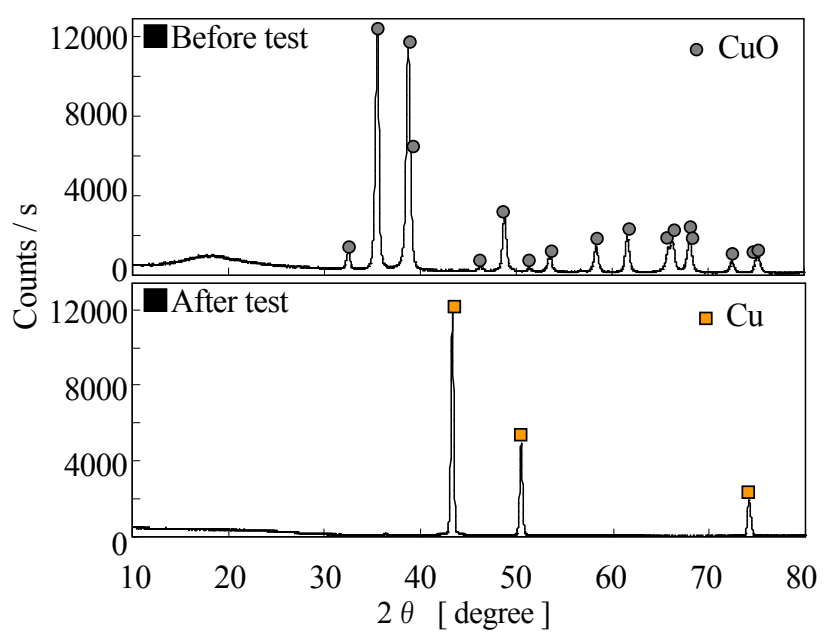

(d) Phenolic resin $+\mathrm{CuO}$

Fig. 15 X-ray diffraction results of test samples before and after the heating test 
Table 7 Compositional formula of test samples before and after the heating test

\begin{tabular}{c|c|c|c}
\hline \multicolumn{2}{c|}{ Sample } & Before test & After test \\
\hline \hline (1) & Phenolic resin & - & - \\
\hline$(2)$ & $\mathrm{Fe}_{3} \mathrm{O}_{4}$ & $\mathrm{Fe}_{3} \mathrm{O}_{4}$ & $\begin{array}{c}\mathrm{Fe}_{3} \mathrm{O}_{4} \\
\alpha-\mathrm{Fe}_{2} \mathrm{O}_{3}\end{array}$ \\
\hline (3) & $\mathrm{CuO}$ & $\mathrm{CuO}$ & $\mathrm{CuO}$ \\
\hline (4) & Phenolic resin $+\mathrm{Fe}_{3} \mathrm{O}_{4}$ & $\mathrm{Fe}_{3} \mathrm{O}_{4}$ & $\begin{array}{c}\mathrm{FeO} \\
\mathrm{Fe}_{3} \mathrm{O}_{4}\end{array}$ \\
\hline (5) & Phenolic resin $+\mathrm{CuO}$ & $\mathrm{CuO}$ & $\mathrm{Cu}$ \\
\hline
\end{tabular}

$\mathrm{X}$ 線回折による各試料のスペクトルおよび組成の同定結果を図 15 および表 7 に示す.

$\mathrm{Fe}_{3} \mathrm{O}_{4}$ の実験結果（図 15 (a)）では，加熱後に $\mathrm{Fe}_{3} \mathrm{O}_{4}$ と $\alpha-\mathrm{Fe}_{2} \mathrm{O}_{3}$ が検出されている. $\mathrm{Fe}_{3} \mathrm{O}_{4}$ に比べ $\alpha-\mathrm{Fe}_{2} \mathrm{O}_{3}$ の $\mathrm{Fe}$ は酸化数が大きく, この場合には $\mathrm{Fe}_{3} \mathrm{O}_{4}$ が酸化されたことを表している.これは, $\mathrm{N}_{2}$ ガスをパージしても雾囲気中 にはわずかな酸素 $\left(\mathrm{O}_{2}\right)$ が残存し, $\mathrm{Fe}_{3} \mathrm{O}_{4}$ が一部酸化されたためと推察される. また, 実験後の試料の一部が赤 色に変化した理由は， $\alpha-\mathrm{Fe}_{2} \mathrm{O}_{3}$ が赤色を呈する(13)ことから説明できる.一方，フェノール樹脂・ $\mathrm{Fe}_{3} \mathrm{O}_{4}$ の混合試料 では, $\mathrm{Fe}_{3} \mathrm{O}_{4}$ の加熱後にみられた $\alpha-\mathrm{Fe}_{2} \mathrm{O}_{3}$ は認められず, $\mathrm{Fe}_{3} \mathrm{O}_{4}$ と $\mathrm{FeO}$ が検出された (図 $15(b)$ ). $\mathrm{Fe}_{3} \mathrm{O}_{4}$ に比べ $\mathrm{FeO}$ の $\mathrm{Fe}$ は酸化数が小さいことから, $\mathrm{Fe}_{3} \mathrm{O}_{4}$ が還元されたことがわかる.

$\mathrm{CuO}$ の実験結果（図 15 (c)）では, 加熱後も $\mathrm{CuO}$ のみが検出され, 加熱前後の組成変化は認められなかった. 一方，フェノール樹脂・ $\mathrm{CuO}$ の混合試料を加熱すると，上記の $\mathrm{CuO}$ を加熱した場合とは異なり, $\mathrm{Cu}$ のみが認め られた（図 15 (d)).つまり, $\mathrm{CuO}$ の還元が確認される. 試験後の試料の色が橙色に変化した原因は, 金属の $\mathrm{Cu}$ が生成されたためである.

以上の結果から，金属酸化物の還元にはフェノール樹脂の分解が関与していることが明らかである．特に，フ エノール樹脂・ $\mathrm{CuO}$ の混合試料を加熱すると金属の $\mathrm{Cu}$ が検出される結果は，添加した金属酸化物が摩擦時に還 元されて生成した金属とディスク材金属との間で，金属同士の摩擦が生じることを強く示唆するものである. 一 方，フェノール樹脂・ $\mathrm{Fe}_{3} \mathrm{O}_{4}$ の混合試料を加熱した実験では，金属の $\mathrm{Fe}$ を検出するに至っていない．この理由と して次の二つが挙げられる，一つは， $\mathrm{Fe}_{3} \mathrm{O}_{4}$ が金属の $\mathrm{Fe}$ まで還元されても， $\mathrm{Fe}$ は $\mathrm{Cu}$ に比べて酸化されや寸いた め, $\mathrm{N}_{2}$ でパージした熱分析装置から取り出すと同時に $\mathrm{Fe}$ の酸化が生じ，金属の $\mathrm{Fe}$ の検出が困難となったことで ある．詳細については後述するが，もう一つはフェノール樹脂を熱分解させた条件と，実際の摩擦面でフェノー ル樹脂が分解する条件が異なることである，すなわち，摩擦を伴わない加熱では金属酸化物を還元する作用が充 分ではなく, $\mathrm{Fe}_{3} \mathrm{O}_{4}$ を $\mathrm{Fe}$ まで還元できなかったことが推察される.

ここで，フェノール樹脂の分解温度と摩擦面温度の関係について述べる. 図 14 から，フェノール樹脂の分解開

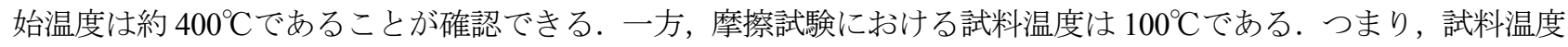
から推定すると，摩擦面ではフェノール樹脂の分解は生じないことになる．しかしながら，摩擦面における真実 接触部では瞬間的に極めて高温になること (閃光温度 ${ }^{(14)}$ ) や，大きな剪断力が加わることによってフェノール 樹脂の低分子化が促進されること ${ }^{(15)}$ が報告されている．また，有機ポリマーとアルミナとの摩擦では，有機ポ リマーの分解によって低分子量のガスが放出されること ${ }^{(16)}$ が明らかになっている. これらの事実から，パッド 材とディスク材の摩擦においても, 摩擦面ではフェノール樹脂が分解するに足る条件となっており, 摩擦面で生 じる金属酸化物の還元は，フェノール樹脂の分解が原因となっているといえる.

\section{4. 金属酸化物還元の機構}

前章の結果から，金属酸化物の還元にはフェノール樹脂の分解が関与していることが明らかとなった．また， 摩擦面でも同様にフェノール樹脂が分解することによって，摩擦還元の原因となることを述べた．ここで，摩擦 還元の本質を把握し，パッド開発における有効な知見を得るために，フェノール樹脂の分解時に金属酸化物が還 元される要因およびその機構について以下の検討を進めた.

フェノール樹脂の分解挙動としては, 分子鎖が切断されることによって,

(A) 分子 $\left(\mathrm{H}_{2}\right.$ や $\mathrm{CH}_{4}$ などの分解ガス)

(B) ラジカル $\left(\mathrm{H} \cdot \mathrm{CH}_{3} \cdot\right.$ など $)$ 
が生じると考えられる.これらの二つが摩擦還元の要因になっていると仮定し, その機構について図 16 のモデル を立てた。ここで，3 章で行った実験に着目寸ると，フェノール樹脂と金属酸化物は接触した状態でフェノール 樹脂が熱分解し，その際に隣接する金属酸化物が還元されたと解釈される.つまり，上記（A），(B) の二つの要 因が含まれた実験結果であることがわかる.

そこで, 本論文では要因 (A)，（B）のいずれが金属酸化物の還元の主因になっているかを調べるため, 図 17 (a) に示したフェノール樹脂・金属酸化物の混合試料に加えて，フェノール樹脂と金属酸化物を分離して加熱する実 験を試みた. 上記（A）に示した分解ガスが摩擦還元の要因であれば，フェノール樹脂が金属酸化物と接触して いなくとも，その分解ガスによって還元されるはずである．実験には 3 章で使用した熱重量測定装置を用いた. また，フェノール樹脂と金属酸化物を分離し，かつフェノール樹脂の分解ガスを確実に金属酸化物と接触させる ため，本論文では多孔質金属を用いた実験方法を考案した。その詳細を図 17 (b)に示寸．白金製セルの底面にフ エノール樹脂を配置し，その上部を多孔質金属で覆い，さらにその上部に金属酸化物をセットした．その外観を 図 18 に示寸．なお，多孔質金属には厚みが約 $2 \mathrm{~mm}$ ，気孔径が約 $600 \mu \mathrm{m}$ ，材質はSUS316 のものを用いた．この ように試料を準備することによって，加熱時に発生した分解ガスは多孔質金属を通ってから金属酸化物と接触す ることになる．この際，分解ガスが還元性を有するならば金属酸化物は還元される．なお，多孔質金属を用いて も金属酸化物の一部はセルの底面に落下してフェノール樹脂と接触する．そのため, 試料の変化は多孔質金属の 上面に残留したものを用いて調べた. また，金属酸化物には $\alpha-\mathrm{Fe}_{2} \mathrm{O}_{3}$ を用いた． $\alpha-\mathrm{Fe}_{2} \mathrm{O}_{3}$ は表 8 に示したように, 還元されると $\mathrm{Fe}_{3} \mathrm{O}_{4}$ や $\mathrm{FeO}$ の生成によって色と磁性に変化が現れ, その場で還元の有無をみる試薬として都合が 良いためである，そこで，加熱前後の試料の色の変化を光学顕微鏡にて調べるとともに，磁石への付着の有無に よって磁性の変化を調べた，なお，多孔質金属を介在させたことによる金属酸化物への影響も調べるため，多孔 質金属と金属酸化物のみをセットした試料（図 17 (c)）を準備し，同条件で比較した。なお，加熱条件は表 5 と 同じとした。実験結果を表 9 に示す.

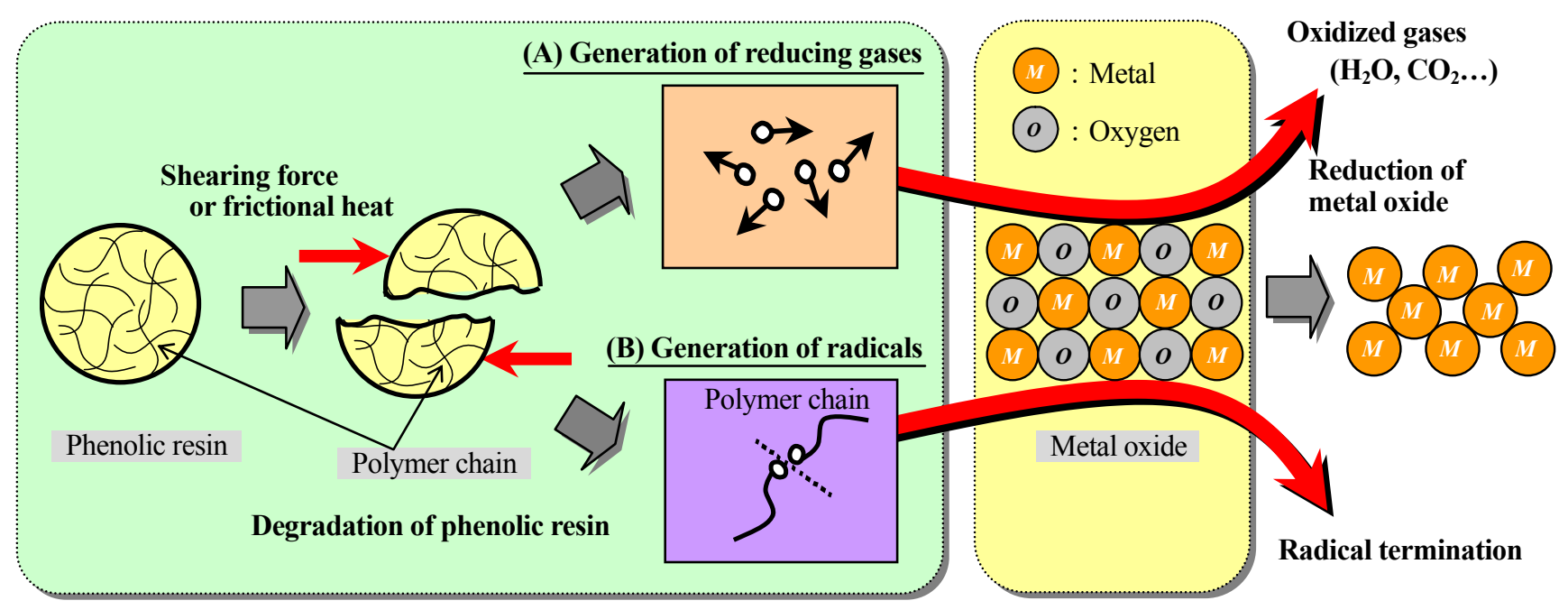

Fig. 16 Tribo-reduction mechanisms of metal oxide in brake pad

Phenolic resin

- Metal oxide $\left(\alpha-\mathrm{Fe}_{2} \mathrm{O}_{3}\right)$

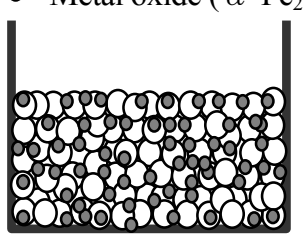

(a) Mixed sample

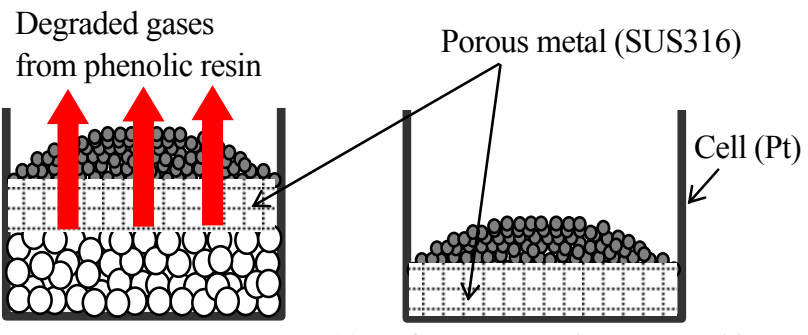

(b) Separated sample (c) Reference sample supported by porous metal without phenolic resin

Fig. 17 Sample setup for heating test 


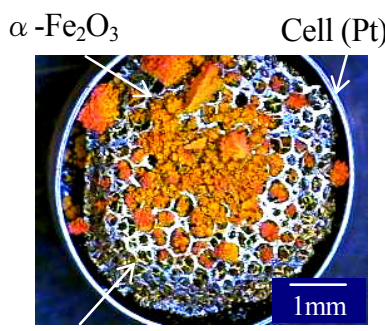

Porous metal (SUS316)
Table 8 Characteristics of iron oxides ${ }^{(13)}$

\begin{tabular}{c|c|c|c}
\hline \multicolumn{2}{c|}{ Iron oxide } & Color & Magnetic \\
\hline \hline$(1)$ & $\begin{array}{c}\alpha-\mathrm{Fe}_{2} \mathrm{O}_{3} \\
(\text { Hematite })\end{array}$ & Red & $\times$ \\
\hline$(2)$ & $\begin{array}{c}\mathrm{Fe}_{3} \mathrm{O}_{4} \\
(\text { Magnetite })\end{array}$ & Black & $\bigcirc$ \\
\hline$(3)$ & $\begin{array}{c}\text { FeO } \\
\text { (Wüstite) }\end{array}$ & Black & $\times$ \\
\hline
\end{tabular}

Fig. 18 Top view of sample setup for heating test type (b) in Fig.17

Table 9 Color and magnetism of test samples before and after the heating test

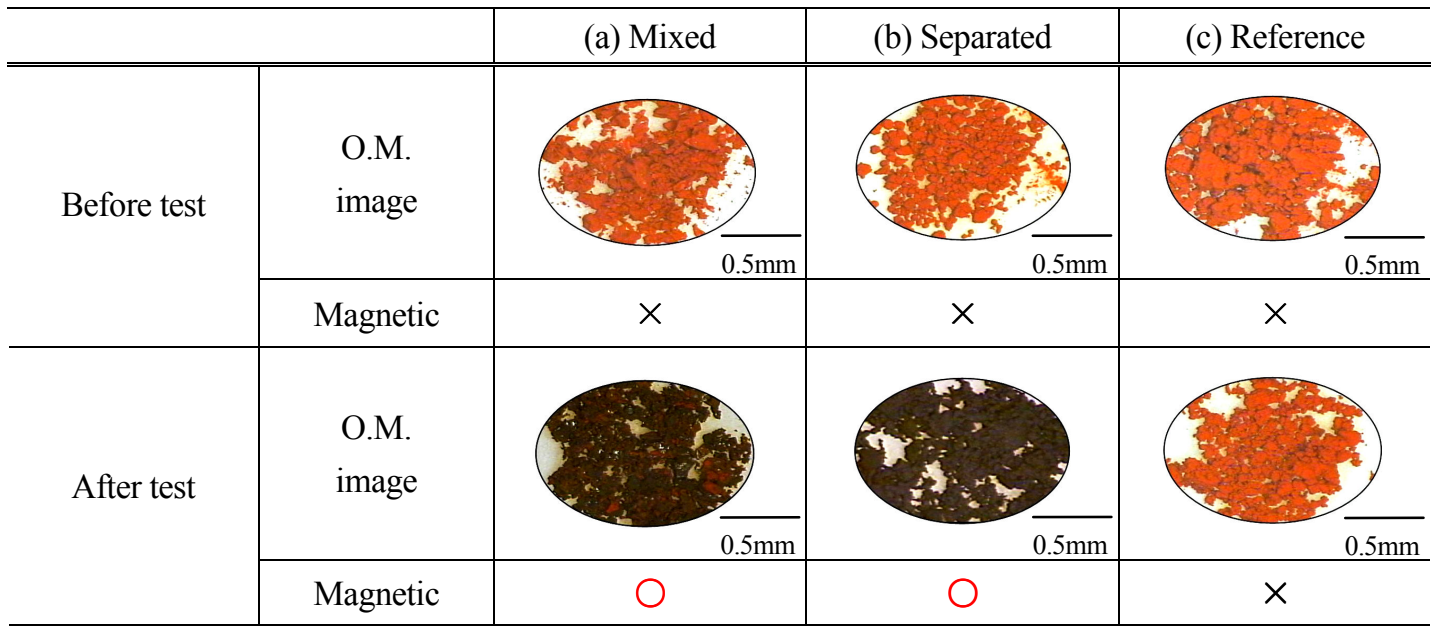

表 9 (a)の試料は，3 章で行った実験と同じようにフェノール樹脂・金属酸化物（ $\left.\alpha-\mathrm{Fe}_{2} \mathrm{O}_{3}\right)$ を混合したものであ る.この試料を加熱すると, 試験後には試料の色が赤から黒に変化するとともに, 試験前にはみられなかった磁 石への付着がみられた。この結果を表 8 に照らし合わせると， $\alpha-\mathrm{Fe}_{2} \mathrm{O}_{3}$ は $\mathrm{Fe}_{3} \mathrm{O}_{4}$ に還元されたことが確認される.

一方，表 $9(\mathrm{~b})$ に示した多孔質金属を用いてフェノール樹脂と $\alpha-\mathrm{Fe}_{2} \mathrm{O}_{3}$ を分離した試料においても，表 9 (a)と同 様に, 試験後の試料の色は赤から黒に変化しており, また試験前にはみられなかった磁石への付着がみられた. つまり，フェノール樹脂と分離して加熱した場合も， $\alpha-\mathrm{Fe}_{2} \mathrm{O}_{3}$ は $\mathrm{Fe}_{3} \mathrm{O}_{4}$ に還元されることがわかる．なお，多孔 質金属を介在させた影響を確認するために準備した試料では，表 9 (c)でも明らかなように，試験前後の色および 磁性に変化がみられなかった。このことから, 表 9 (b)でみられた金属酸化物の還元に対して, 多孔質金属の影響 はなかったことが確認される.

以上の結果から，フェノール樹脂分解時に生じた分解ガスによって金属酸化物が還元されることが明らかとな った. ディスク材とパッド材の摩擦面においても，フェノール樹脂が分解し，生じた分解ガスは金属酸化物を還 元する原因の一つになっていると結論付けられる.ただし，摩擦還元に対するラジカルの影響が否定されたわけ ではなく，その検証は今後の課題である。

\section{5. 結 言}

既報において，フェノール樹脂複合材であるパッド材の摩耗には，添加した金属酸化物の摩擦還元を伴う摩耗 機構が存在し，その要因についてはフェノール樹脂の分解が関与するという仮説を提唱した. 本論文では，上記 の仮説を検証するため, 以下の実験方法を考案した. 一つは, ディスク材の種類を変更して摩耗試験を行った. 通常，パッド材の摩耗試験には鉄系材料の鋳鉄をディスク材に用いるが，本論文では新たに銅をディスク材に用 いた。これは，パッド材に添加した金属酸化物を構成する金属とディスク材の金属が，“ともがね”となるような 試料の組み合わせを作り出し，摩耗試験を行うことによって摩擦還元を検証できると考えたためである．もう一 つは，フェノール樹脂・金属酸化物の混合試料を加熱してフェノール樹脂を分解させる実験から，フェノール樹 
脂の分解が金属酸化物の還元に関与寸ることを検証した.さらに，金属酸化物が還元される要因についても検討 を行った．得られた結論を以下に示す.

(1) 鋳鉄をディスク材に用いた場合, $\mathrm{CuO}$ よりも $\mathrm{Fe}_{3} \mathrm{O}_{4}$ を添加したパッド材の摩耗量が多くなった. 反対に, 夕 フピッチ銅をディスク材に用いた場合には， $\mathrm{Fe}_{3} \mathrm{O}_{4}$ よりも $\mathrm{CuO}$ を添加したパッド材の摩耗量が多くなった. これは，摩擦時に金属酸化物が還元されディスク材と同種金属，すなわち “ともがね”の摩擦が生じること によって, 凝着性の高い状態が発現したためと解釈できる.つまり，この結果はフェノール樹脂複合材の摩 擦時には金属酸化物の摩擦還元が生じることを示している.

(2) フェノール樹脂と $\mathrm{Fe}_{3} \mathrm{O}_{4}$ およびフェノール樹脂と $\mathrm{CuO}$ をそれぞれ混合した試料の加熱実験から, フェノール 樹脂の分解によって金属酸化物が還元されることを示した.この結果から，金属酸化物の摩擦還元の原因に はフェノール樹脂の分解が関係していることを明らかにした。

（3）フェノール樹脂分解時の金属酸化物を還元する要因を解明するため, 多孔質金属を用いてフェノール樹脂と 金属酸化物を分離し，フェノール樹脂を熱分解させる方法を考案し実験を行った．その結果，フェノール樹 脂と金属酸化物を分離してフェノール樹脂を分解させた場合にも, 金属酸化物が還元されることがわかった. これは，フェノール樹脂の分解によって還元性の分解ガスが発生し，それが金属酸化物を還元したためであ る. 摩擦時においても, このフェノール樹脂の分解ガスが摩擦還元の原因の一つとなっていると結論付けら れる.

\section{文献}

(1) 久田慶武, 䒾部誠一郎, “小型・軽量な静肃高機能 ESC モジュレータ”, 自動車技術会学術講演会前刷集, No. 53-07 (2007), pp. 9-12.

（2）藤川裕之，田中俊彦, “ブレーキ摩擦材の技術動向と評価法の規格化”, トライボロジスト, Vol. 53, No. 8 (2008), pp. 512-517.

（3）佐々木要助，日下聡, “自動車ブレーキ用材料の変遷”, トライボロジスト,Vol. 48, No. 3 (2003), pp. 197-201.

(4) 石井勇樹, 西谷要介, 小久保邦雄, 関口勇, 北野武, “フェノール樹脂系複合材料のトライボロジー特性に及ぼすエ ラストマー添加の影響”，トライボロジー会議予稿集 東京 (2011), pp. 187-188.

(5) Okayama, K., Kishimoto, H., Kubota, T., Hiratsuka, K., “A study on the effect of iron oxide $\left(\mathrm{Fe}_{2} \mathrm{O}_{3}\right)$ in a brake pad on pad wear”, Proceedings of World Tribology Congress 2009 Kyoto (2009), p. 131.

(6) 奥田敏晴, “ブレーキシステムの技術動向とトライボロジー”,トライボロジスト, Vol. 54, No. 9 (2009), pp. 592-597.

(7) 岡山勝弥, 小林雅明, 岸本裕也, 久保田辰久, 平塚健一, “フェノール樹脂複合材の摩耗特性に対寸る金属酸化物の 添加効果”, 日本機械学会論文集 C 編, Vol.78, No.791 (2012), pp. 2635-2645.

（8）日本セラミック協会, セラミック工学ハンドブック (1989), pp. 798-816, 技報堂出版.

（9）牧野和孝, 鉱物資源百科辞典 (1999), pp. 447-471, 日刊工業新聞社.

(10) 久保亮五, 長倉三郎, 井口洋夫, 江沢洋, 岩波 理化学辞典, 第 4 版 (1987), p. 831, 岩波書店.

(11) Hiratsuka, K., Yoshida, T., "The twin-ring tribometer - Characterizing sliding wear of metals excluding the effect of contact configurations", Wear, Vol. 270 (2011), pp. 742-750.

(12) 日本潤滑学会, 潤滑ハンドブック (1987), pp. 26-27, 養賢堂.

(13) Godfrey, D., "Iron Oxides and Rust (Hydrated Iron Oxides) in Tribology", Journal of the Society of Tribologists and Lubrication Engineers (1999), pp. 33-37.

(14) 日本トライボロジー学会, トライボロジーハンドブック (2001), p. 22, 養賢堂.

(15) 井上光弘, 原泰啓, 笹田直, “せん断力によるブレーキ材料用フェノール樹脂硬化物の分解 (第 1 報 抽出物の分子量 分布）”, 日本機械学会論文集 C 編, Vol.56, No.521 (1990), pp. 222-227.

(16) Hiratsuka, K., Kodaira, T., Mizuno, H., Sasada, T., "Friction-induced degradation of polymers", Proceedings of the 10th Nordic Symposium on Tribology NORDTRIB 2002, Reg. nr 214 (2002), pp. 1-5. 